\title{
Research Article \\ Hepatoprotective activity of Flacourtia jangomas (Lour.) Raeusch leaves and fruit methanolic extract on paracetamol-induced hepatotoxicity in HepG2 Cells
}

\author{
Akshaya Pai ${ }^{1}$, Chandrakala Shenoy ${ }^{2}$ \\ ${ }^{1}$ Research Scholar, ${ }^{2}$ Professor, Department of Biosciences, Mangalore University, Mangalagangothri, 574199, Dakshina \\ Kannada, Karnataka, India
}

(Received: June $2021 \quad$ Revised: August $2021 \quad$ Accepted: September 2021)

Corresponding author: Chandrakala Shenoy K. Email: chandrakalashenoy2020@gmail.com

\begin{abstract}
Introduction and Aim: Plants have become the current focus of research in treating the various diseases and ailments. Flacourtia jangomas (Lour.) Raeusch belongs to the family Salicaceae. It is a small deciduous fruit tree having immense nutritional and medicinal significance. Different parts of the plant are pharmaceutically used for curing various ailments. In this study, we investigated the hepatoprotective activity of Flacourtia jangomas (Lour.) Raeusch leaves and fruit methanolic extract on Paracetamol induced HepG2 cell line.

Methods: The cytotoxic and hepatoprotective properties were evaluated by measuring cell viability; activities of aspartate aminotransferase (AST), alanine aminotransferase (ALT), and lactate dehydrogenase (LDH); lipid peroxidation (malondialdehyde (MDA) levels).

Results: The increased cell viability of $140.43 \pm 4.07 \%$ and $133.93 \pm 3.20 \%$ was observed in HepG2 cells treated with methanolic extract of $F$. jangomas leaf and fruit extract respectively at $10 \mu \mathrm{g} / \mathrm{ml}$ concentration and then decreased along with the rise of $F$. jangomas leaf and fruit extract concentrations. The level of LDH, ALT, AST and MDA decreased after $F$. jangomas leaf and fruit treatment compared to negative control.

Conclusion: This study suggests that the methanolic Extract of $F$. jangomas (Lour.) Raeusch leaves (FJL) and fruit (FJF) shows hepatoprotective activity in Paracetamol induced HepG2 cell line by the decrease in AST and ALT activities and LDH and MDA level. Hence, it could be considered as a therapeutic agent in curing liver-related diseases.
\end{abstract}

Keywords: Flacourtia jangomas; hepatoprotective; paracetamol; HepG2.

\section{INTRODUCTION}

$\mathrm{L}$ iver plays a vital role in human body in maintaining metabolism and removal of toxic compounds. Free radicals or reactive oxygen species (ROS) may cause oxidative stress leading to improper functioning of liver. Sustained ROS exposure without proper treatment can cause severe liver damage and serious hepatic diseases including cirrhosis (1).

Use of drugs has been a main problem of liver injury hence it is a major challenge in designing potential therapies. Paracetamol toxicity is one of the most common causes of poisoning worldwide. However, Paracetamol is considered as first line pain reliever. Paracetamol is comparatively nontoxic when provided in therapeutic doses but immoderate use of Paracetamol leads to liver injury even liver failure in human. Cytochrome P450 isoforms (CYP2E1, CYP2A6) oxidize paracetamol into a highly reactive metabolite, N-acetyl-para-benzo-quinone imine (NAPQI), which is primarily related to paracetamol hepatotoxicity. NAPQI can be detoxified by covalent binding with glutathione (GSH) in case of non-toxic consumption of paracetamol and when ingested at hepatotoxic doses the majority of the drug is metabolized by CYP2E1 pathway resulting in glutathione depletion which then binds to macromolecules triggering oxidative stress, mitochondrial dysfunction, and ultimately resulting in hepatocellular death $(2,3)$.

HepG2 cells retains many of the biochemical and morphological characteristics of normal hepatocytes hence human hepatoma cell lines have been recommended to be a good substitute to human hepatocytes for in vitro models of normal liver cells to determine hepatoprotective activities of medicinal plants (4).

Flacourtia jangomas (Lour.) Raeusch (family Salicaceae) commonly known as Paniala or Indian plum. Conventionally, different parts of the plant are used to heal various ailments. Sasi et al. reported that the leaves are astringent and stomachic. The fruits are used to overcome various disorders such as to quench thirst, biliousness, fevers, stomach upset and diarrhoea $(5,6)$. Although there were many modern medications available nowadays, the occurrence of hepatic diseases has not reduced. Therefore, the aim of the present work was to investigate the hepatoprotective activity of Flacourtia jangomas (Lour.) Raeusch leaves and fruit methanolic extract on Paracetamol induced HepG2 cell line. 


\section{MATERIALS AND METHODS}

\section{Plant collection and identification}

Flacourtia jangomas (Lour.) Raeusch was collected from Bellikoth, Kasaragod District of Kerala, India. The plant was botanically authenticated and voucher specimen (Accession number KUBH10169) was deposited in the Department of Botany, University of Kerala, Kariavattom, Thiruvananthapuram (6).

\section{Sample preparation of plant extracts}

$F$. jangomas leaves and fruits were collected, shade dried and homogenized to coarse powder and then extracted with methanol in Soxhlet apparatus and the solvent extract were concentrated using a rotary vacuum evaporator and stored at $4^{\circ} \mathrm{C}$ until further use.

\section{Cell culture}

In this study, HepG2 cell line was procured from ATCC $\left(\right.$ ATCC ${ }^{\circledR}$ HB- $8065^{\text {TM }}$ ), stock cells were cultured in Dulbecco's Modified Eagle Media (DMEM) supplemented with $10 \%$ inactivated Fetal Bovine Serum (FBS), penicillin $(100 \mathrm{IU} / \mathrm{ml})$, streptomycin $(100 \mu \mathrm{g} / \mathrm{ml})$ in a humidified atmosphere of $5 \% \mathrm{CO}_{2}$ at $37^{\circ} \mathrm{C}$ until confluent. The cell was dissociated with TPVG solution (0.2\% trypsin, $0.02 \%$ EDTA, $0.05 \%$ glucose in PBS). The viability of the cells was checked and centrifuged. Further, 50,000 cells / well was seeded in a 96 well plate and incubated for $24 \mathrm{~h}$ at $37^{\circ} \mathrm{C}, 5 \% \mathrm{CO}_{2}$ incubator.

\section{Cytotoxicity assay}

Cytotoxicity assay was performed using MTT- [3- (4, 5 - dimethylthiazol-2-yl)-2,5-diphenyl tetrazolium bromide salt]. The cells were treated with different concentrations $(10,20,40,80,160,320 \mu \mathrm{g} / \mathrm{ml})$ of the plant extract and the absorbance was recorded using Spectramax I3X Plate reader at $550 \mathrm{~nm}$.

\section{In-vitro hepatoprotective activity}

The monolayer cell culture was trypsinized and the cell count was adjusted to $1.0 \times 10^{5}$ cells $/ \mathrm{ml}$ using respective media containing $10 \%$ FBS. To each well of the 96 well microtiter plate, $100 \mu 1$ of the diluted cell suspension (50,000 cells/well) was added. The plates were then incubated at $37^{\circ} \mathrm{C}$ for $24 \mathrm{~h}$ in $5 \% \mathrm{CO}_{2}$ atmosphere. Paracetamol at the final concentration of $100 \mu \mathrm{M}$ in cell culture media was used to induce hepatotoxicity in HepG2 cell line. Paracetamol induced cells were incubated for $4 \mathrm{~h}$ in a conventional incubator $\left(37^{\circ} \mathrm{C} ; 5 \% \mathrm{CO}_{2}\right)$. After $4 \mathrm{~h}, 100 \mu \mathrm{l}$ of different test concentrations (10, 20, 40, 80, 160, 320 $\mu \mathrm{g} / \mathrm{ml})$ of test drugs and Silymarin $(1.5 \mu \mathrm{g} / \mathrm{ml})$ were added on to the partial monolayer in microtiter plates. The plates were then incubated at $37^{\circ} \mathrm{C}$ for $24 \mathrm{~h}$ in $5 \%$ $\mathrm{CO}_{2}$ atmosphere and then media containing samples in the wells were discarded. $100 \mu \mathrm{l}$ of MTT $(5 \mathrm{mg} / 10 \mathrm{ml}$ of MTT in 1X PBS) was added to each well and incubated for $4 \mathrm{~h}$ at $37^{\circ} \mathrm{C}$ in $5 \% \mathrm{CO}_{2}$ atmosphere. The supernatant was discarded and $100 \mu \mathrm{l}$ of DMSO was added and the plates were gently shaken to solubilize the formed formazan. The absorbance was measured using a Spectramax I3X Plate reader at a wavelength of $590 \mathrm{~nm}$. The percentage growth inhibition and proliferation were calculated using the following formulae.

Percentage hepatoprotective activity $=((\mathrm{OD}$ of Sample / OD of Control) x 100)-100

\section{Measurement of AST, ALT, and LDH activities}

To evaluate the levels and activity of metabolic enzymes which are elevated in damaged tissues especially in liver tissue, aspartate aminotransferase (AST), alanine aminotransferase (ALT) and Lactate dehydrogenase (LDH) assay were carried out. Cells were pre-treated with Paracetamol $(100 \mu \mathrm{M}$ Concentration) to induce hepatotoxicity in HepG2 cell line. Cells were then treated with $1.5 \mu \mathrm{g} / \mathrm{ml}$ concentration of Silymarin and different test concentrations $(10,80,320 \mu \mathrm{g} / \mathrm{ml})$ of test samples and incubated at $37^{\circ} \mathrm{C}$ for $24 \mathrm{~h}$ in $5 \% \mathrm{CO}_{2}$ atmosphere. The supernatants and cell lysate were taken. ALT and AST activity and LDH levels were determined using kit method (Agatte Diagnostics). All assays were performed as described in manufacturer protocol. The absorbance was measured and the ALT, AST and $\mathrm{LDH}$ levels in IU/L were calculated.

\section{Measurement of lipid peroxidation}

The concentration of MDA, the end product of lipid peroxidation, was measured as described previously by Aguila and Borges (7). After treatment, the medium was discarded from the wells, adherent cells were scraped off and suspended in cold PBS, sonicated, and placed on ice. The supernatant from lysed cells or standard, sodium dodecyl sulphate, and the colour reagent were added to each vial. The vial was heated at $100^{\circ} \mathrm{C}$ for $1 \mathrm{~h}$ and then immediately cooled in an ice bath and centrifuged. The content of each vial was transferred to a well in a microplate. The absorbance of the product was measured at a wavelength of 540 $\mathrm{nm}$ on a microplate reader. The extent of lipid peroxidation was quantified by estimating the MDA concentration. The results were expressed as micromoles of MDA equivalents formed per milligram protein.

\section{Statistical analysis}

The results of hepatoprotective activity were expressed as the mean \pm standard deviation (SD). A statistical analysis was performed with one-way analysis of variance followed by Tukey's multiple comparison tests using Graph Pad Instat Software $(\mathrm{p}<0.05)$.

\section{RESULTS \\ Cytotoxicity}

The in vitro cytotoxic activity of the methanolic extract of $F$. jangomas leaf and fruit was measured by 
the MTT assay against the HepG2 liver cell line at various concentrations. The results of cytotoxicity reveal that $F$. jangomas leaf and fruit extract displayed low level of toxicity to HepG2 cells at all the doses tested in a dose-dependent manner. Results are shown in the figure 1. However, at the highest dosage (320 $\mu \mathrm{g} / \mathrm{ml})$ tested, the extract showed less than $50 \%$ cell death.

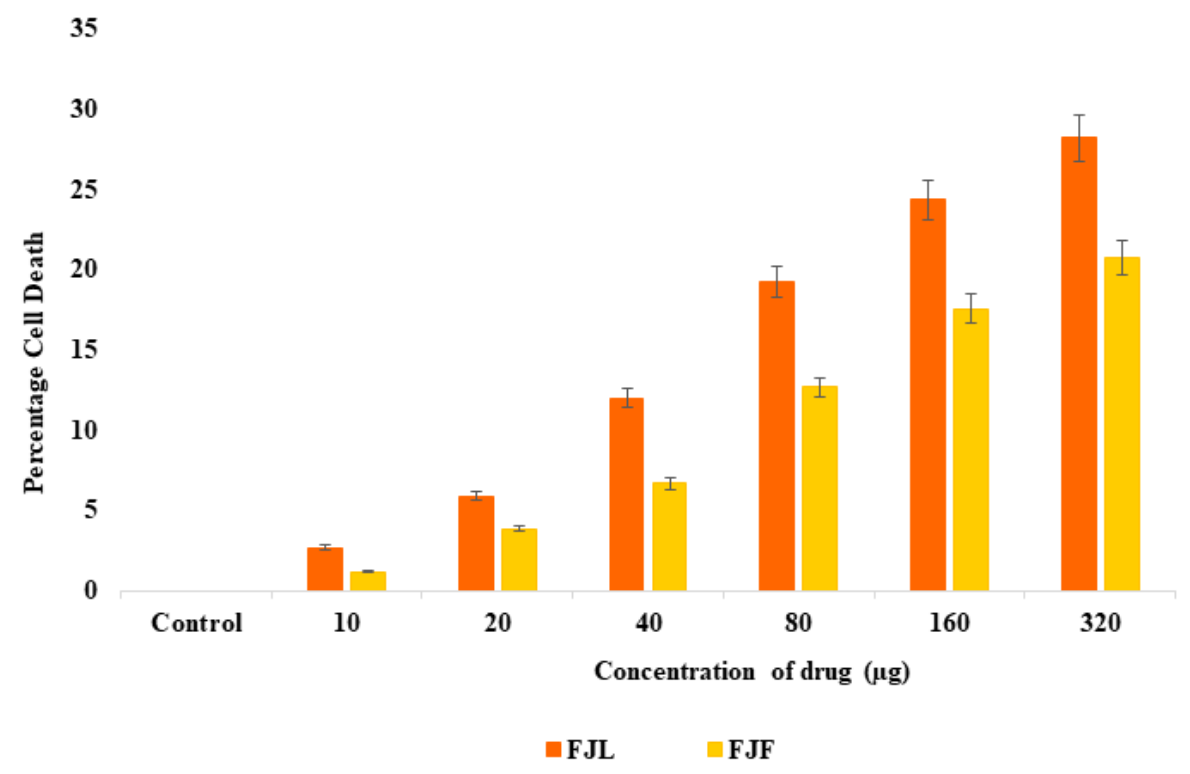

Fig. 1: MTT cytotoxicity effect of the methanolic extract of $F$. jangomas leaf (FJL) and methanolic extract of $F$. jangomas fruit $(\mathrm{FJF})$ in HepG2 liver cells. Data are expressed as percentage of mean $\pm \mathrm{SD}(\mathrm{n}=3)$.

\section{In-vitro hepatoprotective activity}

The percentage cell viability with respect to the normal control (NC) cell lines (HepG2) at different concentrations of methanolic extracts of $F$. jangomas leaves and fruit were determined. The NC HepG2 cells showed $100 \pm 0.07 \%$ and Paracetamol treated HepG2 cells showed $49.08 \pm 0.19 \%$, Silymarin treated on Paracetamol treated HepG2 cells showed $188.31 \pm$ $2.63 \%$ cell viability. The Protective efficacy in presence of paracetamol of methanolic extract of $F$.

a.

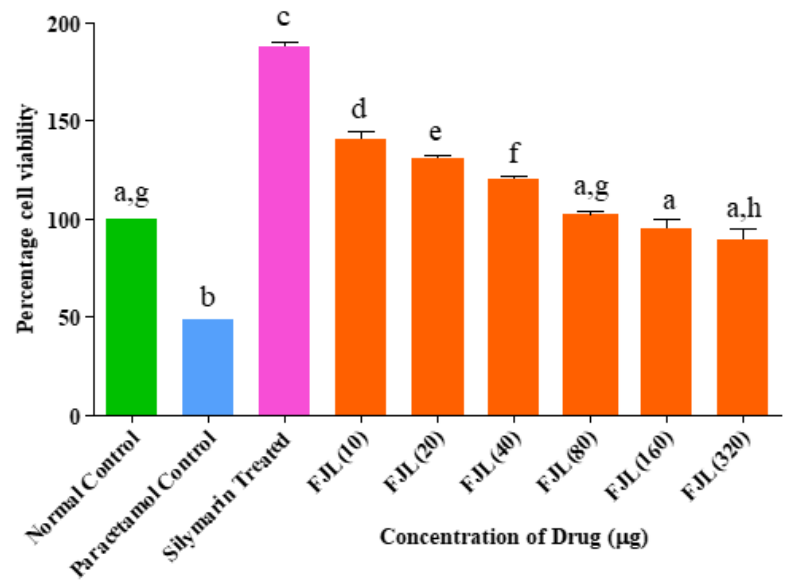

jangomas leaves at concentration $10 \mu \mathrm{g} / \mathrm{ml}, 20 \mu \mathrm{g} / \mathrm{ml}$, $40 \mu \mathrm{g} / \mathrm{ml}, 80 \mu \mathrm{g} / \mathrm{ml}, 160 \mu \mathrm{g} / \mathrm{ml}$ and $320 \mu \mathrm{g} / \mathrm{ml}$ showed $140.43 \pm 4.07 \%, 130.73 \pm 1.96 \%, 120.17 \pm 1.43 \%$, $101.90 \pm 1.68 \%, 95.23 \pm 4.41 \%, 89.69 \pm 5.50 \%$ cell Protection, respectively. The methanolic extract of $F$. jangomas fruit at concentration $10 \mu \mathrm{g} / \mathrm{ml}, 20 \mu \mathrm{g} / \mathrm{ml}$, $40 \mu \mathrm{g} / \mathrm{ml}, 80 \mu \mathrm{g} / \mathrm{ml}, 160 \mu \mathrm{g} / \mathrm{ml}$ and $320 \mu \mathrm{g} / \mathrm{ml}$ showed $133.93 \pm 3.20 \%, 129.17 \pm 1.33 \%, 122.25 \pm 2.09 \%$, $117.31 \pm 1.33 \%, 111.25 \pm 1.94 \%, 103.63 \pm 1.37 \%$ cell protection, respectively (Figure 2).

b.

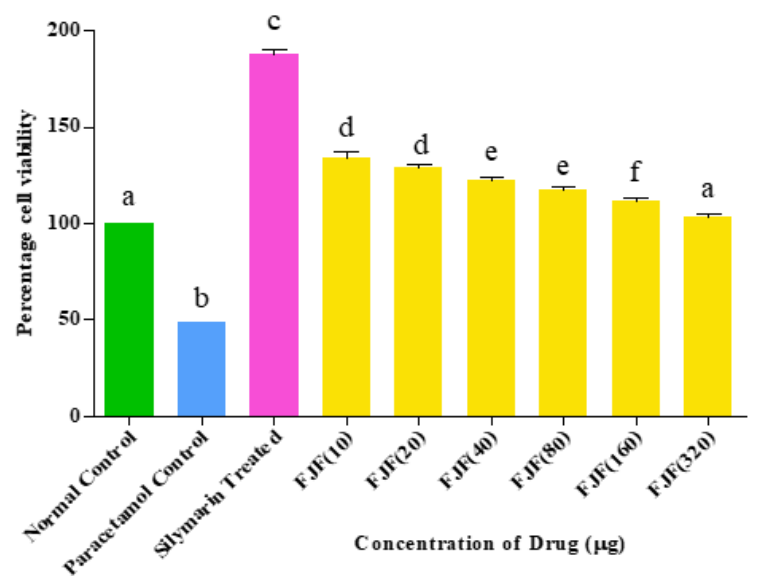

Fig. 2 (a-b): Cell viability of HepG2 after treatment by various concentrations of methanolic extract of $F$. jangomas leaf (FJL) and methanolic extract of $F$. jangomas fruit (FJF). Results are represented as bar chart as percentage of mean \pm standard deviation ( $\mathrm{n}=3$ ) each superscripts $\mathrm{a}, \mathrm{b}, \mathrm{c}, \mathrm{d}, \mathrm{e}, \mathrm{f}, \mathrm{g}$ and $\mathrm{h}$ represents significant differences across the different treatment groups $(\mathrm{p}<0.05)$.

\section{ALT, AST, LDH and MDA Activity}

The toxic effect of paracetamol is shown in Figure 2. The ALT and AST activities can be seen at Figure 3 and 4 after paracetamol induction for 24 hours and it was followed by the treatment with various concentrations of $F$. jangomas leaf and fruit. When compared to negative control (Paracetamol treated) $F$. jangomas leaf and fruit at concentration $10 \mu \mathrm{g} / \mathrm{ml}, 80$ $\mu \mathrm{g} / \mathrm{ml}, 320 \mu \mathrm{g} / \mathrm{ml}$ could reduce the activity of ALT and AST level. This finding clearly revealed that $F$. 
jangomas leaf and fruit at concentration $10 \mu \mathrm{g} / \mathrm{mL}$ had better capacity of reducing AST and ALT activity.

Induction of paracetamol significantly increased LDH level compared to normal cells. $F$. jangomas leaf and fruit at concentration $10 \mu \mathrm{g} / \mathrm{ml}, 80 \mu \mathrm{g} / \mathrm{ml}, 320 \mu \mathrm{g} / \mathrm{ml}$ reduced LDH level when compared to negative

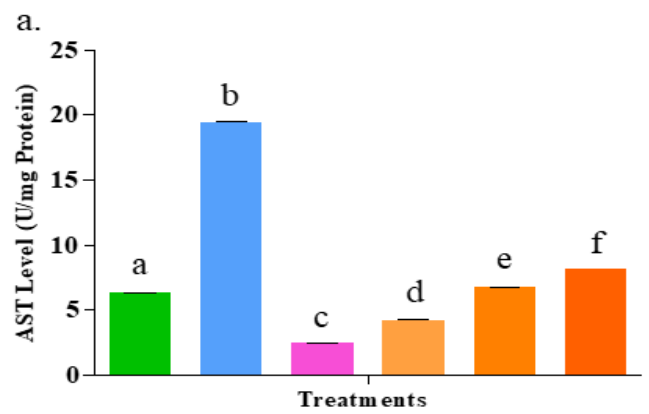

c.

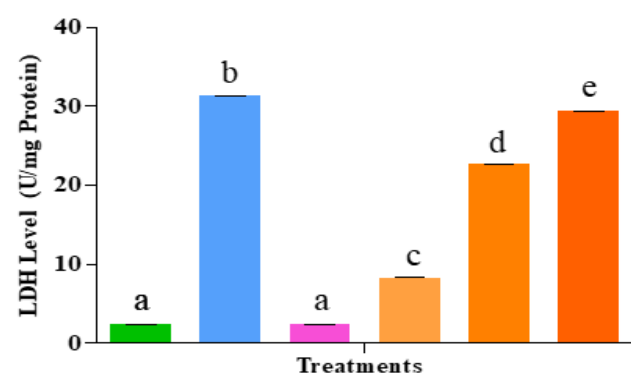

$\begin{array}{lll}\text { Normal Control } & \text { Silymarin Treated } & \text { FJL }(80 \mu \mathrm{g}) \text { Treated } \\ \text { Paracetamol Control } & \text { FJL }(10 \mu \mathrm{g}) \text { Treated } & \text { FJL }(320 \mu \mathrm{g}) \text { Treated }\end{array}$

Fig. 3 (a-d): Effect of methanolic extract of $F$. jangomas leaf (FJL) against damage induced by $100 \mu \mathrm{M}$ paracetamol in HepG2 cells towards AST, ALT, LDH and MDA production. Results are represented as bar chart as mean \pm standard deviation ( $\mathrm{n}=3$ ) each superscripts $a, b, c, d, e$, and f represents significant differences across the different treatment groups $(\mathrm{p}<0.05)$.
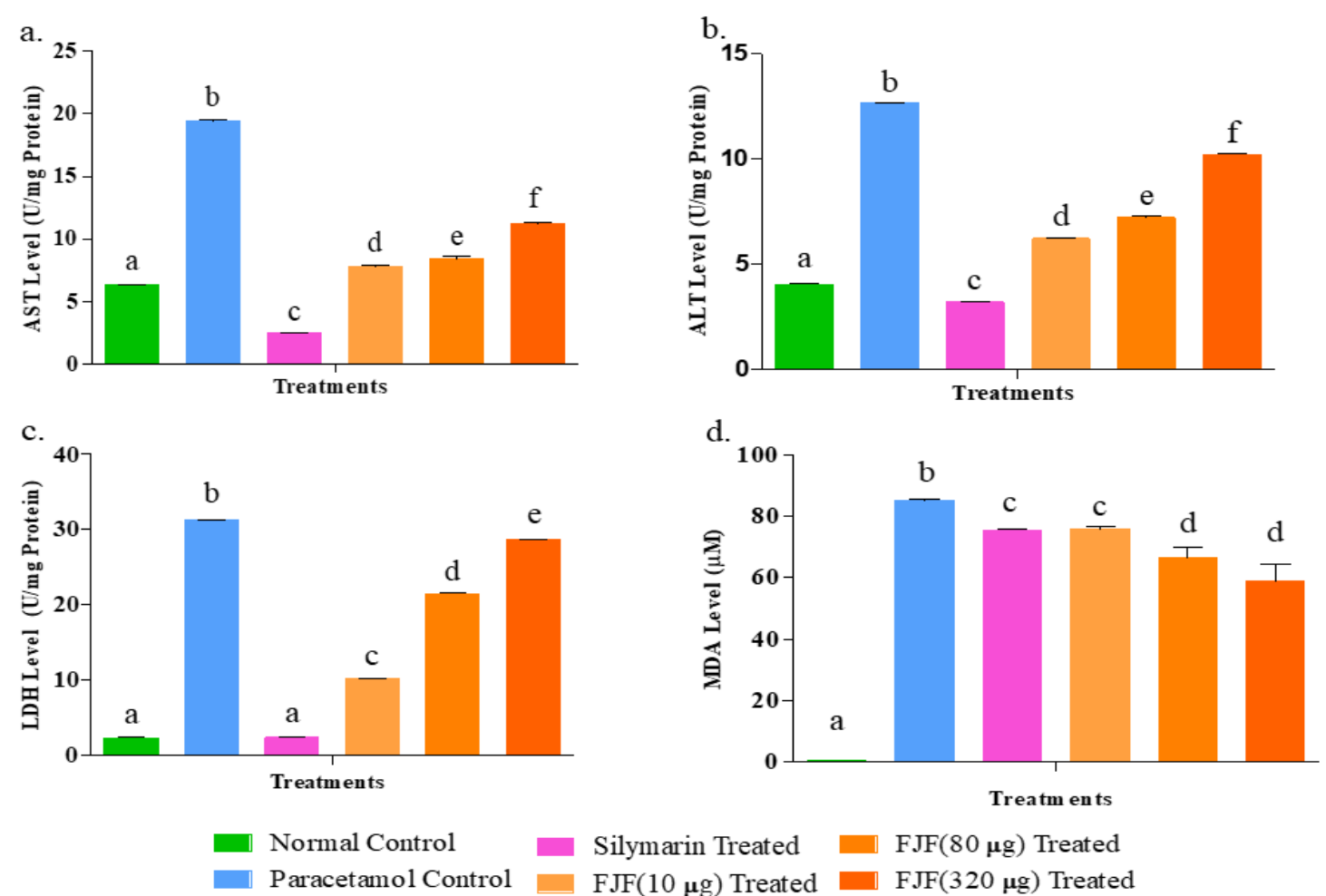

d.

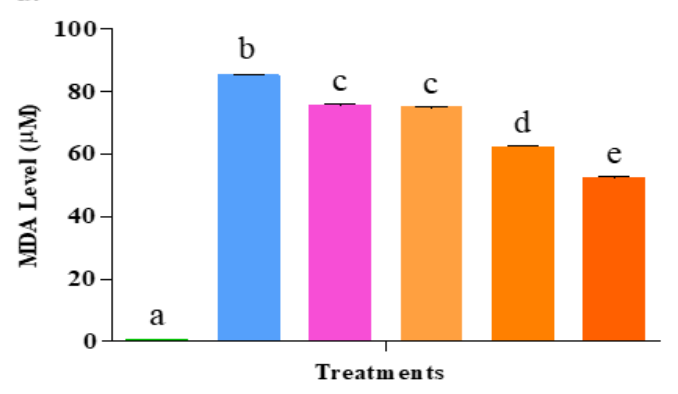

control (Paracetamol treated). MDA levels in the paracetamol treated cells were significantly higher than that in the normal control. The percentages of MDA levels in various concentrations of $F$. jangomas eaf and fruit $(10,80,360 \mu \mathrm{g} / \mathrm{ml})$ were significantly wer than that in the paracetamol-treated cells.

b.

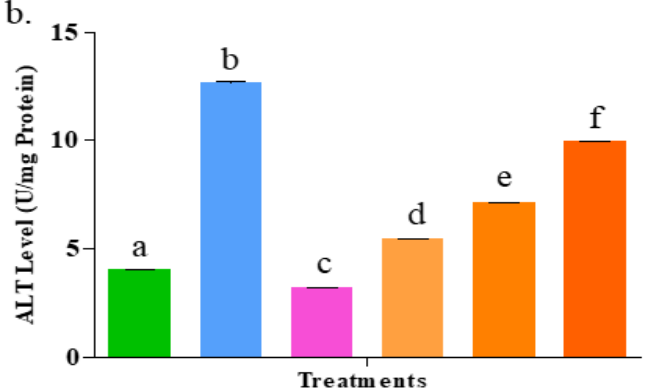




\section{DISCUSSION}

Paracetamol induced hepatotoxicity is often used screening method for checking the hepatoprotective nature of plant extracts. Cellular damage and loss of functional integrity of cell membrane in liver is a sign of hepatic injury (8) and can be measured by checking the aspartate aminotransferase (AST), alanine aminotransferase (ALT), lactate dehydrogenase (LDH) and lipid peroxidation (malondialdehyde (MDA) levels) which are considered as hepatotoxicity markers.

ALT is a metabolic enzyme which is considered more specific for liver disorders because it is mainly present in the cytosol of hepatocytes but in low concentration elsewhere. AST is another enzyme, present in the liver, heart, skeletal muscles, brain, and pancreas (9). In combination with ALT, it is used to detect various liver diseases including alcoholic hepatitis and cirrhosis. The elevation of AST and ALT activities may be attributed to the hepatocellular damage. LDH is a non-organ specific enzyme distributed throughout the body and elevated in different types of damage tissues including skeletal, cardiac muscle, kidney, and liver. LDH levels indicates the increased level of cells necrosis and was regarded as biomarker of cell cytotoxicity (1). Lipid peroxidation and free radicals are involved in the main mechanisms by which hepatotoxins injure hepatocytes (9).

The reduced level of these enzyme in paracetamolinduced hepatotoxicity model after methanolic extract of $F$. jangomas leaf and fruit treatment has clearly proved its hepatoprotective effects. The phytochemical screening of methanolic extract of leaf and fruit of $F$. jangomas showed the presence of alkaloids, glycosides, tannins, flavonoids, phenols (6) and these antioxidant phytochemicals of $F$. jangomas may be responsible for the observed hepatoprotective activity and the active metabolites present in extract gives nutrition to the hepatocytes. The phytochemicals in $F$. jangomas extract may also inhibit lipid peroxidation process, stabilize the hepatocellular membrane and improve the detoxification or excretion capacities (10). Hence, overall results indicates that methanolic extract of $F$. jangomas leaf and fruit possess a potent hepatoprotective activity against paracetamol induced hepatic damage.

\section{CONCLUSION}

The most effective concentration of $F$. jangomas leaf and fruit is seemed to be different in various hepatotoxicity markers tested. However, the decrease in LDH, MDA, AST and ALT level suggests that Methanolic extract of $F$. jangomas leaf and fruit showed the most efficient hepatoprotective activity against paracetamol induced hepatotoxicity on HepG2 cell lines with silymarin as control. However, there is a scope to further quantify the active constituents responsible for hepatoprotective activity.

\section{ACKNOWLEDGEMENT}

The authors acknowledge the Department of Biosciences, Mangalore University, for providing DST-FIST and UGC-SAP supported laboratory facilities and Council of Scientific and Industrial Research University Grants Commission (CSIRUGC), New Delhi, for financial assistance to carry out this work.

\section{CONFLICT OF INTEREST}

The authors declare that there is no conflict of interest.

\section{REFERENCES}

1. Lister, N. E., Ginting, C, N., Girsang, E., Amansyah, A., Chiuman, L., Yanti, N. L. W. E., et al., Hepatoprotective effect of Eugenol on Acetaminophen-Induced Hepatotoxicity in HepG2 cells. Journal of Physics: Conference Series. 2019; 1374 012009. doi:10.1088/1742-6596/1374/1/012009.

2. Ginting, C. N., Lister, N. E., Girsang, E., Widowati, W., Yusepany, D. T., Azizah, A. M., et al., Hepatotoxicity prevention in Acetaminophen-induced HepG2 cells by red betel (Piper crocatum Ruiz and Pav) extract from Indonesia via antioxidant, anti-inflammatory, and anti-necrotic. Heliyon. 2021; 7(1): e05620. doi: 10.1016/j.heliyon. 2020.e05620.

3. Tittarelli, R., Pellegrini, M., Scarpellini, M. G., Marinelli, E., Bruti, V., Di Luca, N. M., et al., Hepatotoxicity of paracetamol and related fatalities. European Review for Medical and Pharmacological Sciences. 2017; 21(1): 95-101.

4. González, L. T., Minsky, N. W., Espinosa, L. E. M., Aranda, R. S., Meseguer, J. P., Pérez, P. C., In vitro assessment of hepatoprotective agents against damage induced by acetaminophen and $\mathrm{CCl} 4$. BMC Complementary and Alternative Medicine. 2017; 17(39). doi: 10.1186/s12906016-1506-1.

5. Sasi, S., Anjum, N., and Tripathi, Y. C., Ethnomedical, phytochemical and pharmacological aspects of Flacourtia jangomas: A review. International Journal of Pharmacy and Pharmaceutical Sciences. 2018; 10(3): 9-15. doi: 10.22159/ijpps.2018v10i3.23998.

6. Pai, A., and Shenoy, K. C., Physicochemical and phytochemical analysis of methanolic extract of leaves and fruits of Flacourtia jangomas (Lour.) Raeusch. International Journal of Pharmaceutical Sciences and Research. 2021; 12(3): 1671-1678. doi: 10.13040/IJPSR.09758232.12(3).1671-78.

7. Aguilar D. D. L. J., and Borges, C. R., Evaluation of Oxidative Stress in Biological Samples Using the Thiobarbituric Acid Reactive Substances Assay. Journal of visualized experiments. 2020; 159: e61122. doi:10.3791/61 122.

8. Kiran, P. M., Raju, A. V., Rao, B. G., Investigation of hepatoprotective activity of Cyathea gigantea (Wall. ex. Hook.) leaves against paracetamol-induced hepatotoxicity in rats. Asian Pacific Journal of Tropical Biomedicine. 2012; 352-356.

9. Abdel-Ghany, R. H., Barakat, W. M., Shahat, A. A., AbdAllah, W. E., Ali, E. A., In vitro and in vivo hepatoprotective activity of extracts of aerial parts of Bidens pilosa L (Asteraceae). Tropical Journal of Pharmaceutical Research November. 2016; 15 (11): 2371-2381. doi: 10.4314/tjpr.v15i 11.11.

10. Bhatt, B. N., Dey, A., Kanjilal, S., Srikanth, H. S., Biswas, R., Chakraborty, P., et al., In vitro hepatoprotective activity of a polyherbal formulation on HepG2 cell line. Ancient science of life 2017; 37: 99-101. doi: 10.4103/asl.ASL_5 $7 \_18$. 